\title{
İç Denetimin Yapısal Ve İşlevsel Sorunlarının Türkiye’deki Üniversiteler Bağlamında Analizi *
}

Erdal BAYRAKCI', Abdullah DEMIREL ${ }^{2}$

${ }^{1}$ Yrd. Doç. Dr., Necmettin Erbakan Üniversitesi, Siyasal Bilgiler Fakültesi, Siyaset Bilimi ve Kamu Yönetimi

${ }^{2}$ Doktora Öğrencisi, Necmettin Erbakan Üniversitesi, Sosyal Bilimler Enstitüsü, Siyaset Bilimi ve Kamu Yönetimi

\begin{abstract}
Özet
Kamu yönetiminde denetim anlayışı özellikle son yıllarda değişim göstermiş ve dış denetiminin yanı sıra kamu kurumları iç denetim kavramı ile de tanışmışlardır. Klasik anlamda kamu idareleri bünyesinde yer alan teftiş birimlerinden farklı olarak ortaya çıkan iç denetim, kaynakların etkili, ekonomik ve verimli kullanılmasının yanı sıra tüm iş ve işlemlerde risk esaslı denetim anlayışını benimsemiştir. 5018 sayılı Kanunla Türk Kamu Yönetimi alanına giren iç denetim sistemi henüz yeni olduğundan birtakım sorunları da beraberinde getirmiştir.

Bu makalenin amacı kamu yönetiminde yeni bir denetim anlayışı olarak ortaya çıkan iç denetimin yapısal ve ișlevsel sorunlarını ele alarak tespitlerde bulunmak ve çözüm önerileri sunmaktır. Bu kapsamda çalışmanın ilk kısmında önce iç denetim kavramı açıklanmış daha sonrada üniversitelerde iç denetimin yapısal ve işlevsel sorunlarını tespit için devlet üniversitelerinde görev yapan iç denetçilere alan araştırması kapsamında anket çalışması yapılmıştır. Son bölümde ise bu anketin değerlendirilmesi yapılarak yapısal ve işlevsel sorunlara çözüm önerileri sunulmuştur.
\end{abstract}

Anahtar Kelime: İç Denetim, Denetim, Yapısal ve İşlevsel Sorunlar, Devlet Üniversiteleri.

\section{Analysis of the Structural and Functional Problems of Internal Audit in The Context of Turkey's Universities}

\begin{abstract}
The concept of auditing in public administration has changed especially in recent years and the public institutions have also met with the concept of internal audit as well as external auditing. In the classical sense, internal audit, which differs from the inspection departments in public administrations, adopts the risk-based audit approach in all business and transactions as well as effective, economic and efficient use of resources. With the Law No. 5018 entering into the field of Turkish Public Administration, the internal audit system has brought some problems with it since it is new.

The purpose of this study is to present the solution proposals by taking into consideration the structural and functional problems of internal audit which emerged as a new audit conception in public administration. The concept of internal audit is firstly explained in the first part of the study, and then a questionnaire is conducted within the scope of the research on the internal auditors who are working at the state universities in order to determine the structural and functional problems of the internal audit at the universities. In the last section, evaluating the questionnaire, suggestion for solutions are presented structural and functional problems.
\end{abstract}

Key Words: Internal Auditing, Auditing, Structural and Functional Problems, State Universities

*Bu Çalışma 2017 yılında Yrd. Doç. Dr. Erdal BAYRAKCI’nın danışmanlığında Abdullah DEMİREL tarafından Necmettin Erbakan Üniversitesi, Sosyal Bilimler Enstitüsü Siyaset Bilimi ve Kamu Yönetimi Anabilim Dalında kabul edilen "Kamu Yönetiminde İç Denetimin Yapısal ve İşlevsel Sorunları: Üniversiteler Üzerine Bir Araştırma" başlıklı Yüksek Lisans tezinden yararlanılarak hazırlanmıştır..

\section{Giriş}

Kamu adına alınan ve uygulanan kararların geleneksel devlet anlayışı içerisinde etkin olması, özellikle sekteye uğrayan ekonomik hayatın ve bundan doğrudan etkilenen kurumların tutunabilmeleri için devletin her alana doğrudan müdahale etmeye başlamasına ve kendini her alanda hissettirmesine neden olmuştur. Böylece devletin bu kadar hayatın içinde olması sorgulanmış; devlete düzenleyici ve denetleyici roller yüklenerek devletin yeniden düzenlenme sürecine girilmiştir.

Türkiye'de, klasik kamu yönetimi anlayışından modern kamu yönetimi anlayışına geçmek adına bir eğilimin mevcut olduğunu söylemek mümkündür. Bu noktada özel kesim tarafindan azami derecede kullanılan iç denetim faaliyeti, son zamanlarda kamu iç mali kontrol sisteminin de ayrılmaz bir parçası haline gelmiştir. Özellikle Avrupa Birliği'ne aday statüdeki ülkelerde, kamuda hesap verilebilirliğin ve mali saydamlığın sağlanmasına yönelik etkili bir iç denetim sisteminin kurulması gerekliliği ortaya çıkmış ve iç denetim sistemi, bu ülkelerin temel kanunlarında, ikincil ve üçüncül mevzuatlarında düzenlenmiştir.

İç denetim sistemi Türkiye'de, 5018 sayılı Kamu Mali Yönetim ve Kontrol Kanunu ile yerini almıştır. Kanun, beraberinde kamu yönetimine yeni kavramlar kazandırmıştır. $\mathrm{Bu}$ kavramlar arasında iç kontrol, iç denetim, stratejik yönetim ve performans yönetimi gibi küresel boyutta yönetim tarzları bulunmaktadır. Bununla birlikte, 5018 sayılı Kamu Mali Yönetimi ve Kontrol Kanunu ile kamu yönetiminde yeni bir denetim anlayışı sunan iç denetim, beraberinde getirdiği sorunların çözülmesi ve etkin bir iç denetim sisteminin hayata geçirilmesi varsayımları ile hazırlanan çalışmanın temel sorunsalı; kamu yönetiminde iç denetim konusunun incelenip, iç denetimin yapısal ve işlevsel sorunlarının tespit edilmesine yönelik algıların belirlenmesidir.

Türk kamu yönetiminde köklü bir geçmişe sahip olmayan iç denetim sisteminin geliştirilmesi ve farkındalık oluşturulması amacıyla akademik alanda bu tür çalışmalara 
ihtiyaç duyulması, iç denetim konusunda özellikle üniversiteler temelinde iç denetimin yapısal ve işlevsel sorunları üzerine çok fazla araştırma yapılmamış olması ve iç denetim konusunda yapılacak olan mevzuat düzenlemelerine 1şık tutacak nitelikte olması bu tür çalıșmalara olan ihtiyacı arttırmıştır.

$\mathrm{Bu}$ çalışmada, iç denetim kavramının analizi yapılarak kamu yönetimi açısından denetim sorunlarının irdelenmesi, iç denetim sisteminin etkinliğini zayıflatan hususların tespit edilmesi ve bu sorunların hangi araçlardan kaynaklandığ ortaya konacaktır. Ardından iç denetim konusunda üniversitelerde görev yapan iç denetçilerin algılarını ölçerek, çalışmada hazırlanan teorik çerçevenin ampirik bir çalışmayla sınanması bu çalışmanın nihai hedefini oluşturmaktadır.

\section{Kavramsal Açıdan Denetim}

Akademik literatürde "denetim" kavramına farklı anlamlar yüklenmiştir. Bu tanımlar; konulara, zamana, yere ve kişilere göre değişebilmektedir. Bu da denetim kavramının ne kadar geniş bir alanda karşımıza çıktığını ve kullanıldığını göstermektedir. Bütün bunlarla birlikte kamu yönetiminde denetim kavramı, bir kurumun, kuruluşun veya bir örgütün belirli bir plan, program veya projenin yapısı, isleyişi ve çıktılarının önceden belirlenmiş standartlara uygunluk seviyesini araştırma, gözlemleme, sorgulama gibi yöntemlerle tespit edilerek belirlenmesi ve elde edilen bulguların nesnel ve sistemli bir biçimde değerlendirilerek ilgili taraflara iletilmesi süreci olarak tanımlanabilir (Köse, 2000:4).

Denetim kavramının bazı unsurları vardır. İlk olarak denetimin belirli amaçlarının bulunması şarttır ki bu amaçlar bir örgütün ana amaçlarıdır. İkinci olarak, denetimin verimlilik unsuru ön plana çıkmaktadır. Belirlenen amaçlara verimli bir biçimde, gerektiğinden fazla para, emek, malzeme ve zaman harcamadan ulaşmak önemlidir. Üçüncü ve son unsur ise zamandır. Önceden belirlenen amaçlara ve ulaşılmak istenen sonuçlara, tahmin edilen zaman içinde ulaşmak gerekmektedir (Köksal, 1998:43).

Denetim bir doğruluk, uygunluk ve akılcılık sorgulaması olarak tanımlandığına göre, bu faaliyetin kendisinin de kalite ve güvenirlik sorgulamasına konu edilmesi gerektiği şüphesizdir. Anılan kalite ve güvenirliğin güvencesi ise, denetimin önceden belirlenmiş ilkelere uygunluğuna bağlıdır (Maliye Hesap Uzmanları Derneği,1996:17): Bu ilkeler; bağımsızlık, yasallık, nesnellik ve dürüstlük olarak siralanabilir. Denetimin temel ilkleri sayılabilecek bu ilkeler denetimin ayrılmaz bir parçası olarak değerlendirilmektedir.

\section{Denetim Türleri}

Denetim çok farklı şekilde tasnif edilerek izah edilebilir. $\mathrm{Bu}$ çalışmanın amacına uygun olarak, denetim türleri amaç ve konumuna göre ve statülerine göre olmak üzere iki grup şeklinde sınıflandırmaya tabi tutularak açıklanmaya çalışılacaktır.

\subsection{Amacina ve Konumuna Göre Denetim}

Amacina göre denetimin uygulanma nedeni, örgüte ait bilgilerin önceden belirlenmiş ölçütlere göre geçen döneme ilişkin bilgilerle karşılaştırmasının yapılarak, ilgili yönetim birimi hakkında belli bir fikre ulaşmayı sağlamaktır (Aksoy,
2002:56). Amacina ve konusuna göre denetimin üç başlik altında incelenmesi yerinde olacaktır.

\subsubsection{Mali (Finansal) Denetim}

Mali (finansal) denetim; basit ve dar anlamda gelir, gider, varlık ve yükümlülüklere ilişkin hesap ve işlemlerin doğruluğunun, mali sistem ve tabloların güvenilirliğinin değerlendirilmesidir (Karaaslan,2006:21). Geniş anlamda ise mali denetim, bir kurumun ya da organizasyonun mali (finansal) tablolarının uluslararası genel kabul görmüş muhasebe teknik ve ilkelerine veya organizasyonun yasal statüsü gereği farklı bir muhasebe sistemine uygun düzenlenip düzenlenmediğini tespit etmeye yönelik, bu tabloların ve bunların dayanağını oluşturan kayıt, belge ve diğer emareler üzerinden yürütülen çalışmalara dayanan ve tespit edilen bulguları denetim raporunda özetleyen sistematik incelemedir(Kaval, 2005:10).6085 sayılı Sayıştay Kanununda ise mali denetim, "Kamu idarelerinin hesap ve işlemleri ile mali faaliyet, mali yönetim ve kontrol sistemlerinin değerlendirme sonuçları esas alınarak, mali rapor ve tablolarının güvenilirliği ve doğruluğuna ilișkin denetimi," olarak tanımlanmıştır (http://www.mevzuat.gov.tr/MevzuatMetin/1.5.6085.pdf, 2016).

Yukarıda verilen tanımlamalar incelendiğinde mali tabloların denetimi ve yorumlanması bir ülkenin geleceğini etkileyebilir. Finansal tablolara bakıldığında kamu kurumlarının, işletmelerin ve diğer organizasyonların içinde bulunduğu durumu tespit etmek, gerekli önemleri almak için son derece önemlidir. Bu mali tablo verileri, tüm kamuoyuna açık olduğu takdirde; yatırımcılara, halka ve diğer yararlanıcılara doğru bilgiler aktararak mali kararlara yön verebilme kabiliyetine sahip olur.

\subsubsection{Uygunluk Denetimi (Hukuki Denetim)}

Uygunluk denetimi, bir kurumun veya kuruluşun mali işlemlerinin ve diğer faaliyetlerinin belirlenmiş usullere, kurallara ve mevzuata uygunluğunun incelenmesidir. Uygunluk denetimi, idarenin tüm birimlerini kapsamaktadır (Aksoy, 2008:38). Bu nedenle, iç denetçiler ile birlikte dış denetçiler, tüm mevzuat hükümlerini göz önüne alarak uygunluk denetimi yapmaktadırlar. Mevzuat hükümleri genel manada başta yasalar olmak üzere tüzük ve yönetmelik hükümleri ile özel manada örgütün ana sözleşme hükümleri, ilke ve standartlara benzer meslek kurallarıdır. Bu manada başta 5018 Kamu Mali Yönetimi ve Kontrol Kanunu ve 6085 sayılı Sayıştay Kanunu sırasıyla iç denetçiler ile dış denetçiler için temel yasal dayanak olmaktadırlar. Kamu Mali Yönetimi ve Kontrol Kanununa dayanılarak çıkarılan ikincil ve üçüncül düzey mevzuat da iç denetçilerin hangi yöntem ve usuller doğrultusunda denetim faaliyetlerini yerine getireceklerini belirlemektedir (Önder, 2008:15-17).

\subsubsection{Faaliyet Denetimi (Performans Denetimi)}

Faaliyet denetimi, bir organizasyon veya işletmenin faaliyetlerini genel olarak etken ve etkin çalışıp çalışmadığını ortaya koymayı amaçlayan bir denetim türüdür. Etkenlik, işletmenin amaç ve hedeflerine ulaşmada başarılı olup olmadığını ölçmeye yaramaktadır. Etkinlik ise; işletmenin amaçlarına ulaşmada kaynakları verimli kullanıp kullanmadığını ölçme görevini yerine getirmektedir (Bozkurt, 2006:23). 
Faaliyet denetiminde denetçiler sadece örgüt içerisinde yürütülen faaliyetlerle değil, bunun yanında yönetsel kontrollerle de ilgilenir. Faaliyet denetiminde denetçi, örgüt politikalarının, iç kontrolün ve örgütün belirlenmiş amaç ve hedeflerine ulaşmasını olumlu ya da olumsuz etkileyecek her türlü faaliyetin başarısını ve etkinliğini değerlemektedir. $\mathrm{Bu}$ nedenle iç denetçilerin örgüt amaçlarının belirlenmesi, politikaların geliştirilmesi gibi örgütün planlama prensipleri konusunda bilgi sahibi olması gerekmektedir. Denetçiler; sorumlulukların belirlenmesi, yetkilerin verilmesi gibi konularda örgüt prensiplerini yakından tanımalıdır (Lawrence at all, 2013:301 akt. Mall1, 2013:48).

Yine ülkemizde performans denetimini yapmakla yetkili olan kurum Sayıştay Başkanlığı olup bu husus 6085 sayılı Sayıştay Kanunu'nda farklı maddelerinde şöyle yer almıştır: "Performans: Kamu idarelerince belirlenen hedef ve göstergelere ulaşma seviyesini" ve "Performans denetimi: Hesap verme sorumluluğu çerçevesinde idarelerce belirlenen hedef ve göstergeler ile ilgili olarak faaliyet sonuçlarının ölçülmesini”, ifade eder.

\subsection{Statüsüne Göre Denetim}

Denetim, denetimi yapan birimlerin statüsü ya da genel anlamda denetimin statüsü açısından üçlü ayırıma tabi tutulabilir. Bunlar; iç denetim, dış denetim ve yüksek denetimdir. İç denetim; iç denetçiler, dış denetim bağımsız dış denetçiler ve kamu denetçileri, yüksek denetim ise parlamentolar adına denetim yapan kamu denetçileri tarafindan yerine getirilir(Arslan, 2008:11).

Bir başka açıdan bakıldığında, denetimi, denetçinin statüsüne göre belirlemek yerinde olacaktır. Bu durumda; denetimi yapan kişi kurum personeli ise bunu iç denetim, kurum dışından bir personel ise bunu da dış denetim olarak niteleyerek bir ayırıma gitmek uygun olacaktır.

İç denetim kısaca; “bir örgütün kendi içinde denetlenmesidir"(Atay, 1999: 38). İç denetim, kuruluşa yönelik bir hizmet olarak o kuruluşun faaliyetlerini incelemek ve değerlendirmek amaciyla kuruluşun bünyesinde oluşturulan bağımsız bir değerlendirme fonksiyonu olarak tanımlanmaktadır(Özen, 2000:1).5018 sayılı Kanunun 63. Maddesinde; "İç denetim, kamu idaresinin çalışmalarına değer katmak ve geliştirmek için kaynakların ekonomiklik, etkililik ve verimlilik esaslarına göre yönetilip yönetilmediğini değerlendirmek ve rehberlik yapmak amacıyla yapılan bağımsız, nesnel güvence sağlama ve danışmanlık faaliyeti" ş̧eklinde tanımlanmıştır.

Dış denetim; kurumun kendi personeli olmayan denetçilerden oluşan, kurumla organik bağı bulunmayan bağımsız ve farklı bir tüzel kişiliği olan denetim organı, grubu veya kişisi tarafindan denetlenmesidir (http://www.alfabetadenetim.com.tr/page.php?sayfa=Yay\%F Dnlar\%FDm\%FDz\&id=6, 2016). Türk Kamu Yönetimi açısından bakıldığında Türkiye'de kamu kurum ve kuruşlarının istisnalar dışında dış denetimi Sayıştay tarafından yapıldığı görülmektedir.

\section{Kamu Yönetimi Açısından Denetim}

Denetim, "kamudaki işlevi bakımından ele alındığında, kamu idarelerinin hukuka uygun faaliyet gösterip göstermediklerini, kamuda üretilen ve açıklanan bilgilerin doğru ve güvenilir olup olmadığını ortaya koymak ve yönetimlerin hesap verme yükümlülüklerinin yerine getirilmesini sağlamak üzere tarafsız ve bağımsız organ veya kişilerce gerçekleştirilen bir faaliyet olduğu anlaşılmaktadır" (Gürkan, 2009:9).

Devletin büyümesi ve yükünün artması ile birlikte kamu yönetimi ve yöneticileri ön plana çıkmıştır. Kamu yönetimi, kamusal işlerle ilgili yapı ve faaliyetlerden oluşur. Kamusal işler, toplum hayatının devletle irtibatlı ortak hizmetlerinden meydana gelir. Vatandaş olarak halk, kamu yönetimini çoğu zaman güçlü, sorun çıkaran ve tek taraflı hareket eden bir örgüt; müşteri olarak ise verimsiz ve bürokratik bir yapı biçiminde değerlendirme eğilimindedir. Kamu yönetimi, bilgi ve uzmanlık kaynağı, karar verme gücü, istikrarlı bir statü ve profesyonellik gibi nitelikleriyle siyasi iktidar karşısında önemli bir güç merkezi haline gelmiştir. Bu gelişmeler karşısında, kamu yönetiminin hizmet yükü ve rolü artmış, buna bağlı olarak verimliliği, etkinliği, denetimi ve hizmet sunduğu çevreye karşı sorumluluğu konuları önem kazanmıştır (Eryılmaz, 2015:367).

Denetimin bu tanımlamaları ve açıklamalarından, "onun bir uzmanlık alanı ve uluslararası tanım ve standartlarda yürütülen bir mesleki faaliyet olduğu anlaşılmaktadır. Bu yönüyle, dünyada denetim, ayrı bir disiplin olarak kabul edilmekte, meslek kuruluşlarının kabul ettiği standart ve etik kurallar çerçevesinde bir mesleki faaliyet olarak yürütülmekte, geleneksel yaklaşımdan farklı olarak da riskli ve önemli alanları dikkate alarak stratejik önceliklere göre yürütülen sürekli ve sistematik bir faaliyet olarak görülmektedir (http://eprints.sdu.edu.tr, 2016).”

Kamu yönetimindeki gelişmeler 1şı̆̆ında kamu kaynaklarının etkili, ekonomik ve verimli olarak kullanılması, mali karar ve işlemlerinin denetlenmesi, raporlanması ve sonuçlarının kamuoyuna sunulması açısından denetim, denetim içerisinde de iç denetimin önemi ön plana çıktığı görülmektedir. İç denetimi diğer denetim türlerinden ayıran en önemli husus risk odaklı denetim anlayışı ve önleyici nitelikte bir yapıya sahip olmasıdır. Kamu yönetimi açısından değerlendirildiğinde denetim alışkanlığını değiştiren, yönetsel işlevleri artıran en etkin bir denetim sistemi olarak karşımıza çıktığı söylenebilir.

\section{Türk Kamu Yönetiminde İç Denetim}

İç denetim, bir kurumun faaliyetlerini geliştirmek ve onlara değer katmak amacını güden bağımsız ve objektif bir güvence ve danışmanlık faaliyetidir. İç denetim, kurumun risk yönetim, kontrol ve yönetişim süreçlerinin etkililiğini değerlendirmek ve geliştirmek amacına yönelik sistemli ve disiplinli bir yaklaşım getirerek kurumun amaçlarına ulaşmasına yardımcı olur(https://www.tide.org.tr/page.aspx?,2016).

İç denetim, kamu yönetimi açısından tanımlanırsa, bir kurum bünyesinde yer alan ve kurum yönetimi tarafindan olası usulsüzlükleri, hataları ve verimsiz uygulamaları asgari seviyeye indirmek amaciyla, kurumun kendini oluşturan tüm sistemlerini ve izleklerini kontrol altında tutmak ve değerlendirmek üzere görev verilen birimin faaliyetidir (Yörüker, 1999:9).

5018 sayılı Kanunun 63. maddesinde iç denetim; "kamu idaresinin çalışmalarına değer katmak ve geliştirmek için kaynakların ekonomiklik, etkililik ve verimlilik esaslarına göre yönetilip yönetilmediğini değerlendirmek ve rehberlik yapmak amacıyla yapılan bağımsız, nesnel güvence sağlama 
ve danışmanlık faaliyetidir. Bu faaliyetler, idarelerin yönetim ve kontrol yapıları ile malî işlemlerinin risk yönetimi, yönetim ve kontrol süreçlerinin etkinliğini değerlendirmek ve geliştirmek yönünde sistematik, sürekli ve disiplinli bir yaklaşımla ve genel kabul görmüş standartlara uygun olarak gerçekleştirilir" denilerek açıklanmıștır.

Yukarıda yapılan tanımlamadan da anlaşılacağı üzere iç denetimin nesnel güvence sağlama ve danışmanlık faaliyetleri olmak üzere iki ayağı bulunmaktadır.

İç denetim, kurumların bir iç hizmeti olup kurumun iç kontrol sistemini ve diğer faaliyetlerini değerlendirmek, denetlemek ve üst yönetime görüş ve önerilerde bulunmak ve aynı zamanda nesnel güvence ve danışmanlık hizmeti veren bir denetim faaliyeti olarak tanımlanabilecektir. İç denetim günümüzde hem özel sektör hem de kamu sektörüne hitap etmekte, karmaşıklaşan ve sürekli gelişen teknoloji ile birlikte modern çağı yakalamak için kaçınılmaz bir yönetim aracı olarak karşımıza çıkmaktadır.

İç denetimin amacına bakıldığında, kurum varlıklarının içerden ve dışarıdan gelebilecek tüm zararlara karşı korunup korunmadığını, faaliyetlerinin önceden belirlenmiş politikalar ile uyumlu gerçekleştirilip gerçekleştirilmediğini araştırmaktır (Güredin, 1994:15). İç denetimin amacı, her türlü riski bularak bertaraf etmektir. Başka bir deyişle iç denetim, kuruluş içinde faaliyetlerin önceden saptanan standartlara, politikalara ve hedeflere uygun bir şekilde yerine getirilip getirilmediğini kontrol eden faaliyetlerin tamamı olarak tanımlanabilir (Saka, 2001:50).

Kamu idarelerinde gerçekleştirilen iç denetim faaliyetleri iç denetimin amacına uygun olarak yürütülmesi ve bir bütün olarak ele alınması gerekmektedir. $\mathrm{Bu}$ faaliyet gerçekleştirilirken farklı yöntemler ve uygulamalara başvurulmalıdır.

Bunlar; kamu idarelerin uymakla yükümlü oldukları, kanun, tüzük, yönetmelik ve diğer düzenlemeler çerçevesinde bu mevzuata uyup uymadıklarının incelenmesi bakımdan uygunluk denetimi, kurumların önceden belirlenmiş olan hedef ve amaçlara ulaşıp ulaşmadığı ölçülmeye çalışan performans denetimi, kamu idarelerinde gelir, gider, varlık ve yükümlülüklere ilişkin hesap ve işlemlerin doğruluğunun ve mali tabloların güvenilirliğinin incelenmesini içeren mali denetim, kamu idarelerinde bilginin toplanması, işlenmesi, depolanması, iletişim ağları aracılığıyla bir yerden bir yere iletilmesi, kullanıcıların hizmetine sunulması, yönetilmesi, saklanması ve güvenliğinin sağlanması ile söz konusu sistemlerde saklanan bilgiye erişim kurallarının belirlenmesinde yararlanılan yazılım ve donanım teknolojilerini kapsayan denetim olan bilgi teknolojileri denetimi ile kamu kurum ve kuruşlarının iç kontrol sisteminin ve faaliyetlerinin teşkilat yapısına artı değer katıcı bir yaklaşımla incelenmesi, varsa eksikliklerinin tespit edilmesi, kalite ve standartlara uygunluğunun araştırılması, kaynakların ve uygulanan usullerin yeterliliğinin ölçülmesi yoluyla değerlendirilmesi olarak adlandırılan sistem denetimlerinden oluşmaktadır(İç Denetçilerin Çalışma Usul ve Esasları Hakkında Yönetmelik; Madde 8).Bu denetim yöntemlerinden bir veya birkaçını kapsayacak şekilde risk esasına dayalı olarak yapılabilir. Bununla birlikte, bir faaliyet ve/veya konu kamu idaresinin tüm birimlerinde denetim kapsamına alınabilir.

Yukarıda sayılan iç denetim faaliyet yöntemleri aslında iç kontrol sisteminin bir parçasıdır. İç kontrol ve iç denetim birbirleri ile yakından ilișkili fakat iki ayrı kavramdır. İç kontrol ve iç denetim uzun senelerden bu yana var olan ancak özellikle son yıllarda zenginleşen ve derinleşen kavramlar olarak karşımıza çıkmaktadır(Korkmaz, 2007:8).5018 sayılı Kanunda iç kontrol; "idarenin amaçlarına, belirlenmiş politikalara ve mevzuata uygun olarak faaliyetlerin etkili, ekonomik ve verimli bir şekilde yürütülmesini, varlık ve kaynakların korunmasını, muhasebe kayıtlarının doğru ve tam olarak tutulmasını, malî bilgi ve yönetim bilgisinin zamanında ve güvenilir olarak üretilmesini sağlamak üzere idare tarafindan oluşturulan organizasyon, yöntem ve süreçle iç denetimi kapsayan malî ve diğer kontroller bütünü’. Şeklinde tanımlanmıştır.

İç kontrol, idarenin faaliyetlerini dinamik bir süreç olarak devam ettirmekte iken, iç denetim bu faaliyetler tamamlandıktan sonra devreye girmektedir. Buna ilaveten iç denetim, iç kontrolün faaliyetlerinin gerçeklemesi esnasında yönetime danışmanlık hizmeti de sunabilir. İç denetimin, yönetime, iç kontrole yönelik değerlendirmelerde bulunması ve önemli bilgiler aktarması, iç kontrolün ikamesi anlamında değerlendirilmemelidir (Kayım, 2006:86).

Tablo 1. Özellikleri Bakımından İç Denetim ve İç Kontrolün Karşılaştırılması

\begin{tabular}{|l|l|}
\hline \multicolumn{1}{|c|}{ İÇ DENETIM } & \multicolumn{1}{c|}{ İÇ KONTROL } \\
\hline $\begin{array}{l}\text { 1.Bilginin doğruluğunu ve } \\
\text { güvenilirliğini test edip, } \\
\text { yönetime güvence vermek. }\end{array}$ & $\begin{array}{l}\text { 1.Bilginin doğruluğunu ve } \\
\text { güvenilirliğini sağlamak. }\end{array}$ \\
\hline $\begin{array}{l}\text { 2.Plan, program ve mevzuata } \\
\text { uygunluğu kontrol etmek. }\end{array}$ & $\begin{array}{l}\text { 2.Plan, program ve mevzuata } \\
\text { uygunluğu gerçekleştirmek. }\end{array}$ \\
\hline $\begin{array}{l}\text { 3.Etkinlik ve verimliliği teşvik } \\
\text { ederek artı değer kazanmak. }\end{array}$ & 3.Etkinlik ve verimlilik sağlamak. \\
\hline $\begin{array}{l}\text { 4.Risk denetimi suretiyle } \\
\text { bağımsız ve tarafsı faaliyette } \\
\text { bulunmak. }\end{array}$ & $\begin{array}{l}\text { 4.Başta yönetimce belirlenen } \\
\text { hedeflere ve iç ve dış denetime } \\
\text { hizmet etmek. }\end{array}$ \\
\hline
\end{tabular}

Kaynak:(Toroslu, 2014:5)

\section{5. Üniversitelerde İç Denetimin Yapısal ve İşlevsel Sorunlarına Yönelik Bir Araştırma}

Bu başlık altında, üniversitelerdeki iç denetim sisteminin yapısal ve işlevsel sorunlarına, bu idarelerde görev yapan iç denetçilerin iç denetim sistemine olan yaklaşımlarına ilişkin yapılan araştırmanın içeriğine ve bulgularına değinilmiştir.

\subsection{Araştırmanın Amacı ve Yöntemi}

Çalışmada üniversitelerde iç denetim faaliyetlerinin ne aşamada olduğu, iç denetim sisteminin kurumsal alt yapısının oluşturulup oluşturulmadığı, rektörün (üst yönetici) iç denetçi ve iç denetim faaliyetleri karşısındaki tutumu, 2007 yılından itibaren mesleğe alınan iç denetçilerin iç denetim sisteminin sorunları hakkındaki düşünceleri ve mesleğe bakış açıları, üniversitelerin kendi personel rejiminden kaynaklı sorunlarına iç denetçilerin verdiği cevaplar bağlamında tespitlerde bulunmak ve bu sorunlara çözüm önerisi sunmak amaçlanmıştır.

$\mathrm{Bu}$ bağlamda üniversitelerde iç denetim sisteminin yapısal ve işlevsel sorunlarının tespiti ve değerlendirilmesi üzerine yapılan çalışmada kullanılan anket formu iki ana bölümden oluşturulmuştur. Anketin birinci bölümünde 
katılımcıların cinsiyeti, yaşı, eğitim durumlarını tespit etmeye yönelik sorulara, anketin ikinci bölümünde ise, iç denetimin yapısal ve işlevsel sorunlarını tespit etmek amacıyla ilgili olarak toplam10 adet soruya yer verilmiştir. Çalışmanın amacını gerçekleştirebilmek için veri toplama aracı olarak nicel araştırma yöntemlerinden birisi olan anket tekniği tercih edilmiştir.

\subsection{Araştırmanın Evreni ve Örneklem Seçimi}

Araştırmanın kapsamını Türkiye'de devlet üniversitesinde çalışan iç denetçiler oluşturmaktadır.07.04.2017 tarihi itibariyle İDKK verilerine göre Türkiye'de var olan 118 devlet üniversitesinde istihdam edilmesi öngörülen toplam 369 iç denetçi kadrosunun 231'i dolu, 165 adedi hali hazırda boştur. 118 devlet üniversitesinin 22 tanesinde ise şuana kadar iç denetçi ataması gerçekleştirilmemiştir ${ }^{*} .118$ devlet üniversitesinin 22 tanesinde hiç iç denetçi ataması gerçekleştirilmediğinden kalan 96 devlet üniversitesinin internet sitesinden toplam 133 iç denetçinin iletişim adreslerine ulaşılmıștır. İç denetçilerin adreslerine elektronik posta yoluyla gönderilen anket çalışması 17 Ekim-17 Kasım 2016 tarihleri arasında gerçekleştirilmiştir. Belirlenen süre sonunda bu çevrimiçi anket formuna toplam 31 iç denetçi cevap vermiştir. Geri dönüşlerin artırılması için bazı iç denetçilerle doğrudan görüşülmüş bazı iç denetçilere ise hatırlatma e-postaları gönderilerek geri dönüşümler artırılmıştır. Bu aşamada 29 iç denetçi daha ankete dâhil olmuş ve toplamda 60 anket değerlendirmeye alınmıştır.

\subsection{Araștırma Bulgularının Analizi}

Araştırmanın birinci bölümünde katılımcıların demografik bilgilerini ölçmek amacıyla frekans ve yüzde dağılım analizlerinden yararlanılmıştır. İkinci bölümde iç denetçilerin üniversitelerdeki iç denetimin yapısal ve işlevsel sorunlarına verdikleri cevaplar yüzde ve frekans dağılımları ile birlikte değerlendirilmiştir.

\subsubsection{Katılımcıların Demografik Özellikleri}

Çalışmanın bu bölümünde katılımcıların cinsiyeti, yaşı ve eğitim durumları tespit edilmeye çalışılmıştır.

Tablo 2. Katılımcıların Demografik Özellikleri

\begin{tabular}{|c|c|c|}
\hline Cinsiyet & Sayı (n) & Yüzde (\%) \\
\hline Kadın & 9 & 15 \\
\hline Erkek & 51 & 85 \\
\hline Toplam & $\mathbf{6 0}$ & $\mathbf{1 0 0}$ \\
\hline Yaş & & 3,3 \\
\hline $25-30$ & 2 & 6,7 \\
\hline $31-35$ & 4 & 33,3 \\
\hline $36-40$ & 20 & 15,0 \\
\hline $41-45$ & 9 & $\mathbf{1 0 0}$ \\
\hline Toplam & $\mathbf{6 0}$ & 63,3 \\
\hline Eğitim Durumu & & 26,7 \\
\hline Lisans Mezunu & 38 & 10,0 \\
\hline Yüksek Lisans & 16 & $\mathbf{1 0 0 , 0}$ \\
\hline Mezunu & 6 & $\mathbf{6 0}$ \\
\hline Doktora Mezunu & & \\
\hline Toplam & &
\end{tabular}

Araştırmaya katılan iç denetçilerin demografik özellikleri incelendiğinde; katılımcıların (\% 85 ) 51'i erkek, (\% 15) 9'u ise kadındır.

*Iç Denetim Koordinasyon Kurulu'na yapılan bilgi edinme kapsamında elde edilen verilerden derlenmiştir.
Yaş dağılımı açısından bakıldığında katılımcıların (\% 3,3) 2 kişi 25-30 yaş arası, (\% 6,7 ) 4 kişi 31-35 yaş arası, (\% 33,3) 20 kişi 36-40 yaş arası ve $(\% 41,7) 25$ kişi ise 46 yaş ve üzeri olduğu tespit edilmiştir.

İç denetçilerin eğitim durumları incelendiğinde; (\% 63,3) 38 kişi lisans mezunu, (\% 26,7) 16 kişi yüksek lisans mezunu ve $(\% 10) 6$ kişi ise doktora mezunu olduğu görülmüştür.

\subsubsection{Katılımcıların Üniversitelerde İç Denetim Sorunlarına Yönelik Düşünceleri}

Çalışmanın bu bölümünde katılımcıların üniversitelerde iç denetim mekanizmasının sorunlarına yönelik düşüncelerini tespit ve analiz edebilmek amacıyla katılımcılara iç denetim mekanizmasının yapısal ve işlevsel sorunları şeklinde iki ana başlık altında toplanan bir dizi önerme verilmiștir. Bu önermelere katılımcıların verdikleri cevaplar üzerinden üniversitelerde iç denetim mekanizmasının sorunları hakkında analiz yapılmaya çalışılmıştır.

\subsubsection{Katılımcıların İç Denetimin Yapısal Sorunlarına Yönelik Düşünceleri}

Katılımcıların üniversitelerde iç denetimin yapısal sorunlarına yönelik düşüncelerini tespit edebilmek için kendilerine beş adet önerme verilmiş ve bu önermelere ne derece katıldıkları sorulmuştur. İlk olarak katılımcılara "Üniversitelerde iç denetim yapılanmasına ihtiyacın olmadığını düşünüyorum" şeklinde bir önerme verilmiş ve verilen cevaplar Grafik 1'de düzenlenmiştir.

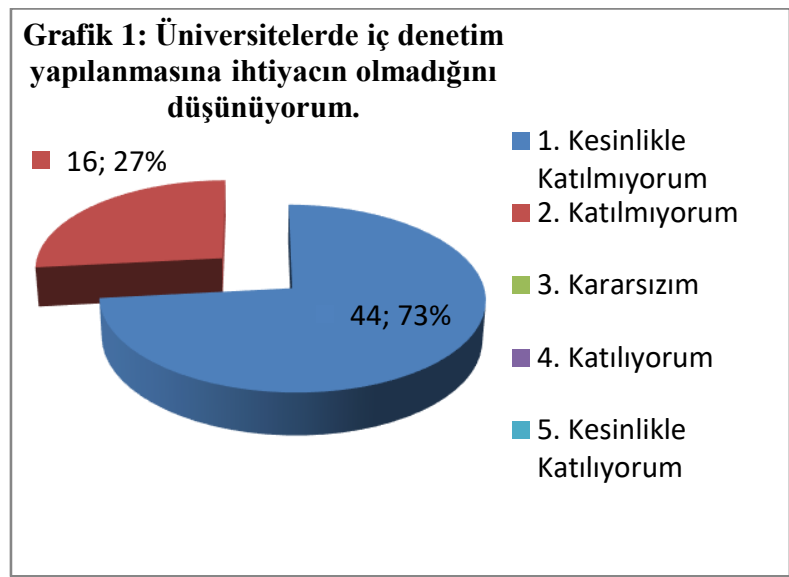

"Üniversitelerde iç denetim yapılanmasına ihtiyacın olmadığını düşünüyorum" önermesine ankete katılan iç denetçilerden 44 kişi (\% 73) kesinlikle katılmıyorum ve 16 kişi(\% 27) ise katılmıyorum cevabını vermiştir.Verilen cevaplar değerlendirildiğinde katılımcıların tamamının üniversitelerde iç denetim yapılanmasının var olması gerektiği görüşünü desteklediği şekilde yorumlanabilir.

İkinci olarak katılımcılara üniversitelerdeki personel yapısının iç denetime etkisinin değerlendirilmesi amacıyla "Üniversitelerdeki akademik ve idari kadro ayrışması iç denetimi olumsuz etkiler" ş̧eklinde bir önerme verilmiş ve verilen cevaplar Grafik 2'de düzenlenmiştir. 


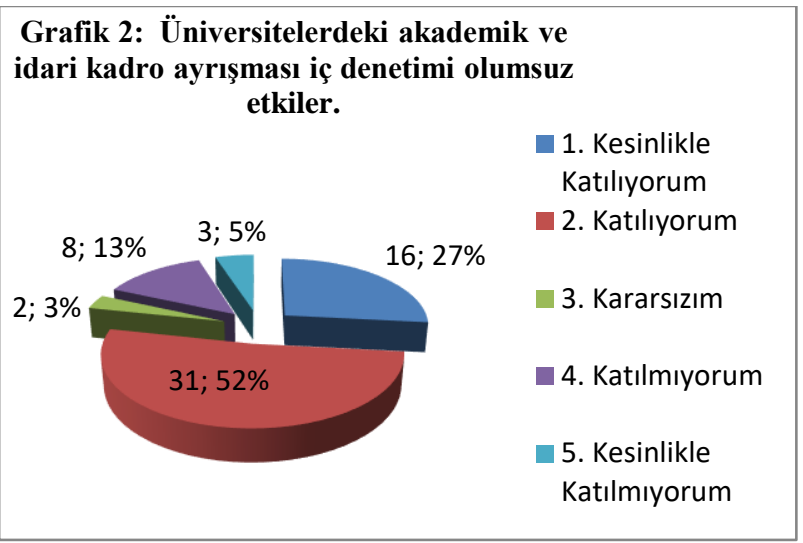

Grafik 2'de görüldüğü gibi ankete katılan iç denetçilerden 16 kişi(\% 27) kesinlikle katılıyorum, 31 kişi( $\%$ 52) katılıyorum, 2 kişi( $\%$ 3) $\quad$ kararsızım, 8 kişi $(\% \quad 13)$ katılmıyorum ve 3 kişi( $\%$ 5) ise kesinlikle katılmıyorum cevabını vermiştir. Verilen cevaplar değerlendirildiğinde ankete katlan iç denetçilerin yaklaşık \% 79’u, bu tür kadro ayrışmasının iç denetimi olumsuz etkilediği görüşünü savunduğu görülmüştür. Üniversitelerde, hem 2914 sayılı Yükseköğretim Personel Kanunu hem de 657 sayılı Devlet Memurları Kanununa göre personel istihdam edilmektedir. İç denetçiler de doğrudan üst yöneticiye bağlı olan idari personel olarak görev almaktadır. Bu durum farklı personel statüsündeki çalışanların gerek iç denetime bakış açıları gerekse iç denetime yaklaşımları arasındaki farklar temel sebepler olarak değerlendirilebilir.

Üçüncü olarak, iç denetim mevzuatının yapısal ve işlevsel yeterliliğinin değerlendirilmesi amacıyla "Mevcut iç denetim mevzuatı yapısal ve işlevsel anlamda yeterlidir." şeklinde bir önerme verilmiş ve verilen cevaplar Grafik 3'de düzenlenmiştir.

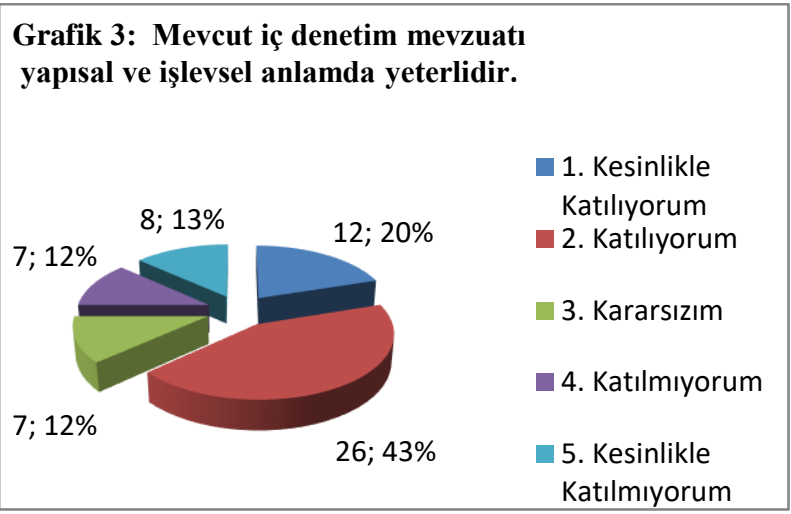

Grafikte görüldüğü üzere ankete katılan iç denetçilerden 12 kişi(\% 20) kesinlikle katılıyorum, 26 kişi(\%43) katılıyorum, 7 kişi $(\% \quad 12) \quad$ kararsızım, 7 kişi $(\% \quad$ 12) katılmıyorum ve 8 kişi( $\%$ 13) ise kesinlikle katılmıyorum cevabını vermiştir.Verilen cevaplar değerlendirildiğinde ankete katılan iç denetçilerin yaklaşık \% 63'ü iç denetim mevzuatının yapısal ve işlevsel anlamda yeterli olduğu görüşünde olduğu görülmüştür.

Dördüncü olarak, iç denetim koordinasyon kurulu ile iç denetim birimleri arasındaki ilişkilerin değerlendirilmesi amacıyla "İç denetim koordinasyon kurulu ile iç denetim birimlerinin bağları kuvvetlidir." şeklinde bir önerme verilmiş ve verilen cevaplar Grafik 4'de düzenlenmiştir.

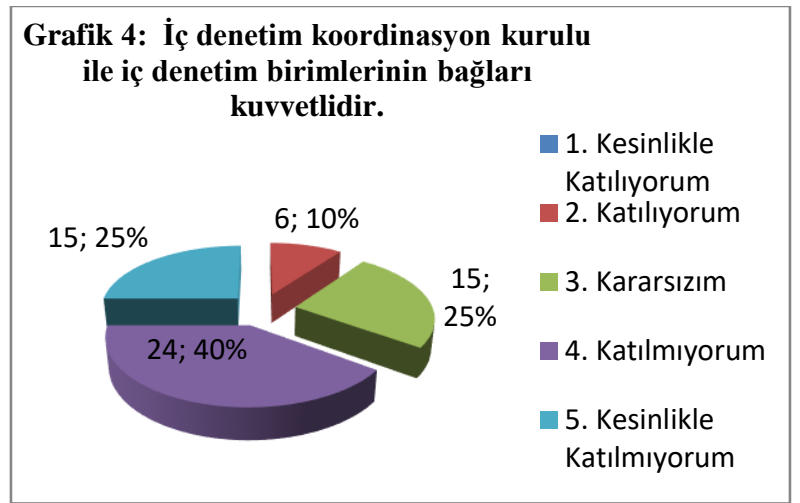

Ankete katılan iç denetçilerden 6 kişi(\% 10) katılıyorum, 15 kişi(\% 25) kararsızım, 24 kişi(\% 40) katılmıyorum ve 15 kişi(\% 25) ise kesinlikle katılmıyorum yanıtını vermiştir. Verilen cevaplar değerlendirildiğinde ankete katılan iç denetçilerin \% 65'i iç denetçilerin, İç Denetim Koordinasyon Kurulu ile iç denetim birimlerinin bağlarının kuvvetli olmadığ1 yönünde görüş bildirmişlerdir. İç Denetim Koordinasyon Kurulunun görevlerine bakıldığında iç denetim birimleri ile Kurulun arasındaki ilişkinin sıkı bir şekilde kurulduğu halde bu ilişkinin iç denetim birimleri ile kuvvetli kurulamadığ 1 yönündedir.

Katılımcıların üniversitelerde iç denetimin yapısal sorunlarına yönelik düşüncelerini tespit edebilmek için son olarak, "İç Denetçiler üst yönetici tarafindan değil, doğrudan iç denetim koordinasyon kurulu tarafından atanmalı." şeklinde bir önerme verilmiş ve verilen cevaplar Grafik 5'de düzenlenmiştir.

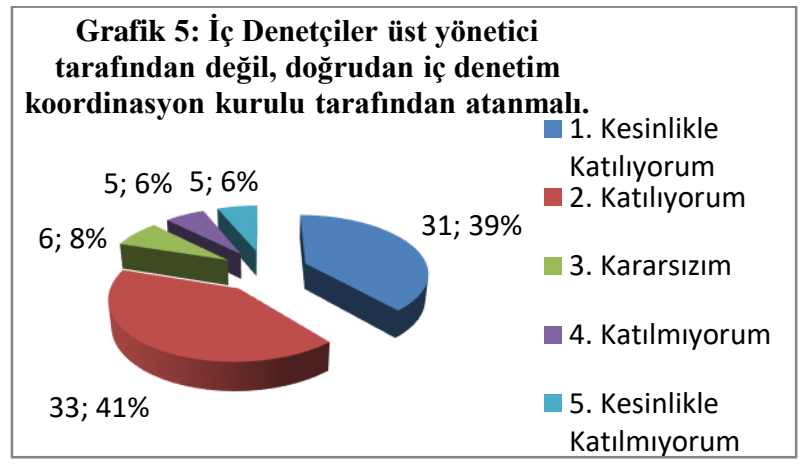

Ankete katılan iç denetçilerden 31 kiși (\% 39) kesinlikle katılıyorum, 33 kişi (\% 41) katılıyorum, 6 kiși (\% 8) kararsızım, 5 kişi( $\%$ 6) katılmıyorum ve 5 kişi(\% 6) ise kesinlikle katılmıyorum cevabını vermiştir.Verilen cevaplar değerlendirildiğinde ankete katılan iç denetçilerin yaklaşı \% 80 'i iç denetçilerin üst yönetici tarafından değil, doğrudan İDKK (İç Denetim Koordinasyon Kurulu) tarafından atanmalı önermesine katıldığı görülmüştür. 5018 sayılı Kanunun 65'inci maddesinin son fikrasında; “İç denetçiler, bakanlıklar ve bağlı idarelerde, üst yöneticilerin teklifi üzerine Bakan, diğer idarelerde üst yöneticiler tarafından sertifikalı adaylar arasından atanır ve aynı usulle görevden alınır." hükmü yer alır. Bu kanun hükmü gereğince iç denetçilerin üst yönetici tarafın atanacağı belirtilerek iç denetçilerin atandığı idareye bağlı bir personel olarak görev yapacağı ifade edilmiştir. $\mathrm{Bu}$ durumun iç denetçilerin bağımsızlık fonksiyonunun zedeleyeceği, denetim sahasında kendilerini rahat hissetmeyeceği gibi tereddütlerin oluşacağından, iç denetçiler, iç denetçilerin üst yönetici tarafından değil doğrudan İDKK tarafindan atanması yönünde görüş bildirdiği düşünülmektedir. 
5.3.2.2. Katılımcılarınİç Denetimin İşlevsel Sorunlarına Yönelik Düşünceleri

Katılımcıların üniversitelerde iç denetimin işlevsel sorunlarına yönelik düşüncelerini tespit edebilmek için kendilerine beş adet önerme verilmiş ve bu önermelere ne derece katıldıkları sorulmuştur.

İlk olarak, iç denetimin üniversitelerde etkinliğinin tespiti amacıyla "Üniversitelerde iç denetim etkin çalışıyor." şeklinde bir önerme verilmiş ve verilen cevaplar Grafik 6' da düzenlenmiştir.

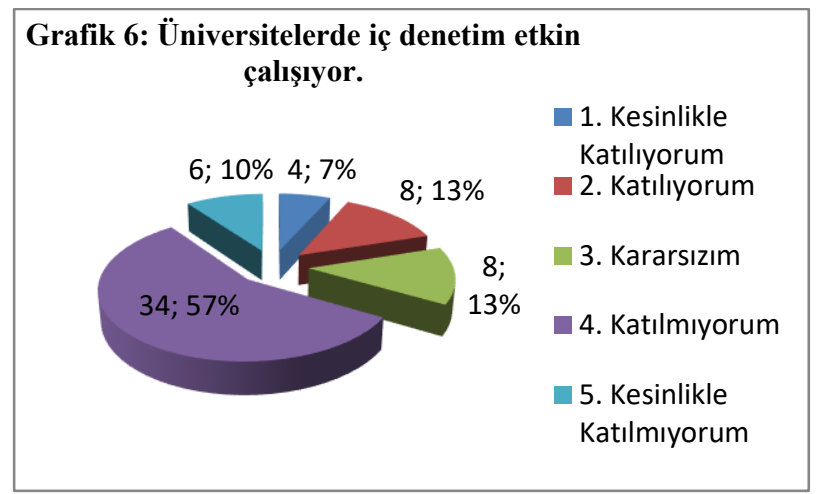

Ankete katılan iç denetçilerden 4 kişi( $\%$ 7) kesinlikle katılmıyorum, 8 kişi $(\%$ 13) katılmıyorum, 8 kişi ( $\%$ 13) kararsızım, 34 kişi $(\%$ 57) katılıyorum ve 6 kişi $(\%$ 10) ise kesinlikle katılıyorum şeklinde yanıt vermişlerdir. Verilen cevaplar değerlendirildiğinde ankete katılan iç denetçilerin \% 67'si iç denetimin üniversitelerde etkin çalışmadığını ifade etmişlerdir. $\mathrm{Bu}$ durum üniversitelerde iç denetim alanında görece bir farkındalığın henüz oluşmadığı ve işlevsel anlamda iç denetimin geliştirilmesi gerektiği yönde değerlendirmek mümkün olabilecektir.

İkinci olarak, iç denetçilerin denetim güçlüğü çektiği alanların olup olmadığının tespiti amacıyla "Denetim güçlüğü çekilen alanlar mevcut." şeklinde bir önerme verilmiş ve verilen cevaplar Grafik 7'de düzenlenmiştir.

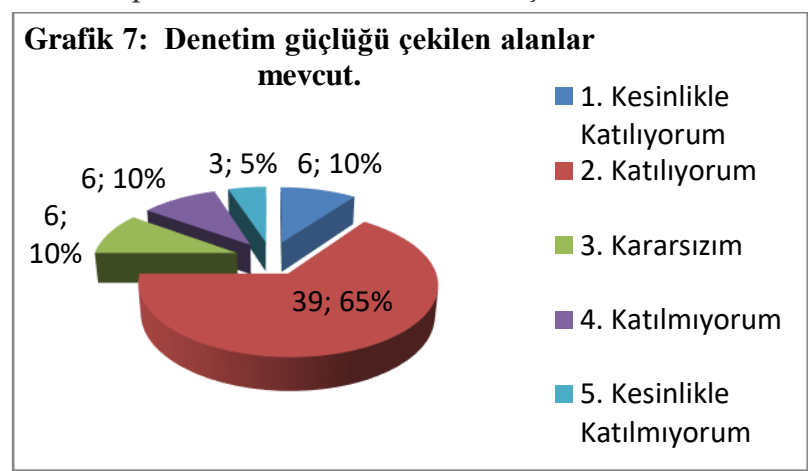

Ankete katılan iç denetçilerden (\% 10) 6 kiși kesinlikle katılıyorum, 39 kişi(\% 65) katılıyorum, 6 kişi(\% 10) kararsızım, 6 kişi( $\%$ 10) katılmıyorum ve 3 kişi $(\% 5)$ ise kesinlikle katılmıyorum cevabını vermiştir.İç denetçilerin konu ve kişi bazında denetim yapmasına engel bir durum olmadığ1 mevcut düzenlemelerden anlaşılmaktadır. Ancak ankete katılan denetçilerin $\% 75$ 'i denetim güçlügü çekilen alanların mevcut olduğu cevabını vermişlerdir. Bu oran, üniversiteler için değerlendirildiğinde, oldukça yüksektir. İç denetçinin denetim güçlügü çektiği alanlar ne kadar çoksa iç denetimin etkinliği bir o kadar az olacaktır.

Üçüncü olarak, üst yönetimin iç denetime desteğinin ne yönde olduğunun tespiti amacıyla "Üst yönetici iç denetime destek veriyor" önermesi verilmiş ve katılımcıların cevapları Grafik 8'de verilmiştir.

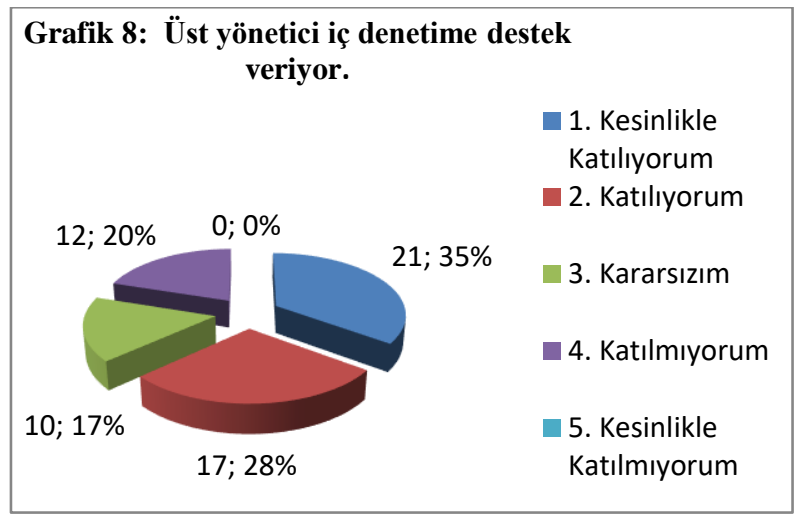

Anketi cevaplayan iç denetçilerden 21 kişi( $\%$ 35) kesinlikle katılıyorum, 17 kişi(\% 28) katılıyorum, 10 kişi $(\%$ 17) kararsızım ve 12 kişi( $\%$ 20) katılmıyorum yanıtını vermiştir. Verilen cevaplar değerlendirildiğinde üst yöneticilerin iç denetime verdiği destek oranı \% 63'tür. Buradan hareketle İç denetim sisteminin üniversitelerde yeni yeni farkındalık oluşturulmaya başladığı, üst yöneticilerin destek vermeye başladığı şeklinde değerlendirmede bulunulabilir. Ancak toplam 22 üniversiteye hiç iç denetçi ataması yapılmaması ve bazı üniversitelerde kadroların doldurulmaması üst yöneticilerin bu konuda isteksizliğini ortaya koyar niteliktedir.

Dördüncü olarak, üniversitelerde iç denetim faaliyetlerinin bağımsızlığının tespiti amacıyla "İç denetim faaliyetlerini bağımsız bir şekilde, müdahale olmaksızın yürütebiliyorum.” önermesi verilmiş ve katılımcıların cevapları Grafik 9'da verilmiştir.

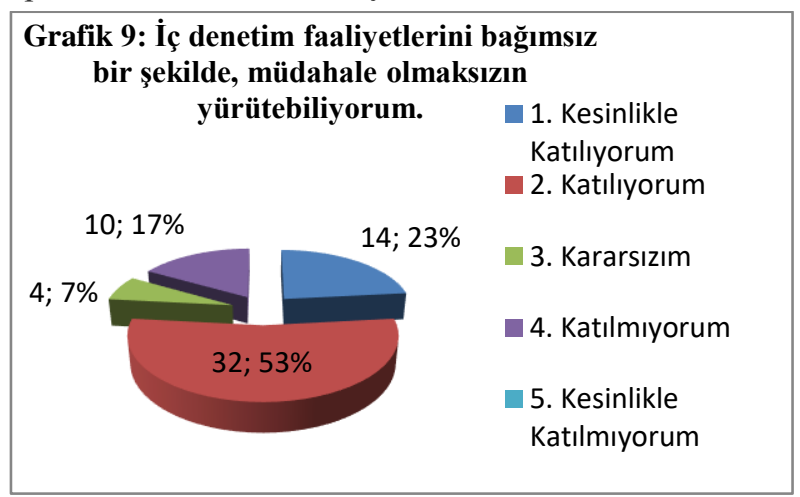

Ankete katılan iç denetçilerden 14 kişi(\% 23) kesinlikle katılıyorum, 32 kişi( $\%$ 53) katılıyorum, 4 kişi(\% 7) kararsızım ve 10 kişi(\% 17) katılmıyorum cevabını vermiştir. Verilen cevaplar değerlendirildiğinde ankete katılanların \% 76'sı iç denetçilerin denetim faaliyetlerinde bağımsız olduklarını ifade etmiştir. $\mathrm{Bu}$ oran işlevsel anlamda iç denetimin etkinliğini sağlaması yönünden beklenen bir ortalama olmasına karşın tam anlamıyla beklentileri karşılamamaktadır. Çünkü iç denetime ve denetim sonrası hazırlanan raporlara yapılan en küçük müdahaleler bile iç denetimin tarafsızlığını olumsuz yönde etkileyebilmektedir.

Katılımcıların üniversitelerde iç denetimin işlevsel sorunlarına yönelik düşüncelerini tespit edebilmek için son olarak, "İç denetimin kurumunuza artı değer kattığını düşünüyorum.” önermesi verilmiş ve katılımcıların cevapları Grafik 10'da verilmiştir. 


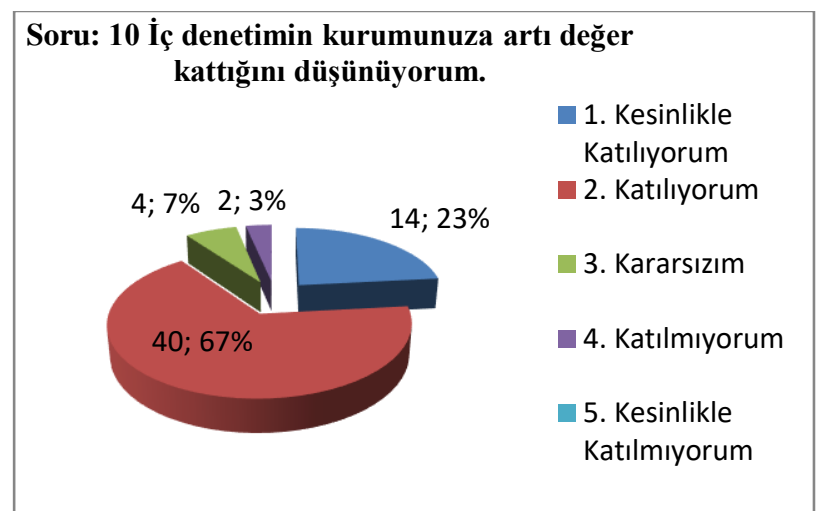

İç denetim faaliyetlerinin kurum çalışmalarına etkisinin değerlendirilmesi amacıyla sorulan bu soruya katılımcılardan 14 kişi( $\%$ 23) kesinlikle katılıyorum, 40 kişi( $\%$ 67) katılıyorum, 4 kişi( $\%$ 7) kararsızım ve 2 kişi( $\%$ 3) ise katılmıyorum cevabını vermiştir. Verilen cevaplar değerlendirildiğinde ankete katılanların yaklaşık \% 90'ı iç denetimin kurumlarına artı değer kattığını düşünmektedir. Kanunun 63'üncü maddesinde iç denetim tanımı yapılırken, iç denetimin kamu idaresinin çalışmalarına değer katmak olduğu hususu ilk vurgulanan özelliklerden biri olarak karşımıza çıkmaktadır. Çünkü iç denetim klasik anlamda bir denetim anlayışını terk ederek kamu idaresinin çalışmalarına artı değer katan ve risk odaklı bir denetim anlayışına kavuşmuştur. $\mathrm{Bu}$ nedenle iç denetimin işlevsel anlamda sağlayacağı faydaların en önemlisi olarak görülebilir.

\section{Sonuç}

Birçok ülkede uzun yıllardan beri uygulanan iç denetim sistemi, Türkiye'de de öncelikli olarak özel sektör tarafından uygulanmaya başlanmış ve birçok büyük şirket uluslararası standartlar çerçevesinde gerçekleştirilen iç denetim sistemini firmalarında uygulamışlardır. 5018 sayılı Kamu Mali Yönetimi ve Kontrol Kanunu'nun 2003 y1lında yürürlüğe girmesiyle iç denetim sistemi kamu kurum ve kuruluşlarında da uygulanmaya başlanmıştır. Kanunla birlikte, iç denetim sistemi ve Türk mali yönetim sisteminde birçok değişiklik meydana gelmiştir. İç denetim ile kamu idarelerinin daha etkin ve verimli bir şekilde çalışması, kaynakların rasyonel kullanımı hedeflenmiştir.

Türk kamu yönetiminde, iç denetim sistemi açısından uluslararası standartlarda mevzuat alt yapısı genel olarak tamamlanmış durumdadır. Kurumlarda mali ve mali olmayan tüm süreçlerin aynı unvanda, aynı rehber ve standartlara göre aynı merkezi uyumlaştırma biriminin fonksiyonel işbirliğinde denetlenmesi yerinde bir uygulamadır. Bu sistemin kamu yararına uygun ve etkin bir şekilde uygulanabilmesi için değişimin, taraflara iyi anlatılması ve sürecin iyi yönetilmesi gerekir. Burada en önemli görev merkezi uyumlaştırma birimi olan İç Denetim Koordinasyon Kurulu'na düşmektedir.

Çalışma kapsamında ulaşılan sonuçlar şu şekilde siralanabilir:

- Üniversitelerde iç denetim sisteminin yer alması gerekliliği ön plana çıkmaktadır.

- Üniversitelerde iç denetim sisteminin etkin olmadığ görülmüștür. Bunun nedenleri arasında üst yöneticinin iç denetim sistemini desteklememesi ve çalışanlar tarafından iç denetim sisteminin benimsememesi gösterilebilir.
- Üniversitelerde iç denetim farkındalık düzeyinin görece diğer kamu kurum ve kuruluşlarına göre düşük olduğu söylenebilir. Bundaki temel sebepler üniversitelerin ülke geneline yayılmış olmasından dolayı merkezi uyumlaşma süresinin daha yavaş işlemesi, üniversitelerdeki akademik ve idari kadro ayrışmasının iç denetimi olumsuz etkilemesi şeklinde sıralanabilir. Bugün üniversitelerde mevcut olan iç denetçi kadrolarının hatırı sayılır derecede boş olması ki en az 22 devlet üniversitesinin hiç iç denetçi ataması yapmaması, rektörlerin iç denetim konusunda yeterli bilgiye sahip olmaması bu olumsuz durumu tetikleyen nedenler arasında sayılabilir.

- Üniversitelerde iç denetçilerin denetim güçlüğü çektiği alanların mevcut olduğu görülmüştür. İç denetçilerin denetim güçlüğü çektiği alanlar ne kadar çoksa iç denetimin etkinliği bir o kadar az olacaktır. $\mathrm{Bu}$ durumun sebeplerine bakıldığında, üniversitelerin özerk bir yapıya sahip olması, üniversitelerde akademik ve idari gibi ikili kadro ayrışmasının olması, iç denetçinin üst yöneticiye bağlı olarak konumlandırılması ve iç denetim birimlerinin istenen personel sayısına ulaşamaması sonucu etkili denetim yapamaması gibi nedenler sayılabilir.

- Üniversitelerdeki akademik ve idari kadro ayrışmasının iç denetim faaliyetlerini olumsuz etkilediği söylenebilir. Üniversitelerde, hem 2914 sayılı Yükseköğretim Personel Kanunu hem de 657 sayılı Devlet Memurları Kanununa göre personel istihdam edilmektedir. İç denetçiler de doğrudan üst yöneticiye bağlı idari personel olarak görev almaktadır. $\mathrm{Bu}$ durumun iç denetime bakış açısını etkilediği ve iç denetim algısını değiştirdiği söylenebilir.

- İç Denetim Koordinasyon Kurulu ile iç denetim birimlerinin arasındaki ilişkinin zayıf olduğu görülmüştür. İç Denetim Koordinasyon Kurulunun görevlerine bakıldığında iç denetim birimleri ile Kurulun arasındaki ilişkinin sıkı bir şekilde kurulduğu görülmüş ancak bu durumun gerçeği yansıtmadığı söylenebilir.

İç denetçilerin üst yönetici tarafından değil, doğrudan İDKK tarafindan atanmalı görüşünün iç denetçiler arasında hakim olduğu görülmüştür.

\section{Kaynaklar}

Aksoy, Mehmet(2008),Kamuda İç Kontrol ve İç Denetim, Muhasebat Kontrolörleri Derneği Yayınları, Ankara.

Aksoy, Tamer(2002),Tüm Yönleriyle Denetim, Yetkin Hukuk Yayınları.

Aslan, Bayram(2008), Türk Kamu Mali Yönetiminde İç Denetim, Yayınlanmamış Yüksek Lisans Tezi, Kırıkkale Üniversitesi SBE.

Atay, Cevdet(1999),Devlet Yönetimi ve Denetimi, Alfa Yayınları, İstanbul.

Bozkurt, Nejat(2006), Muhasebe Denetimi, Alfa Yayınları, 4. Bask1, İstanbul.

Eryılmaz, Bilal(2015),Kamu Yönetimi, 8. Bask1, Umuttepe Yayınları, Kocaeli.

Güredin, Ersin(1994),Denetim, Beta Yayınları. 
Gürkan, N.Zarifi,(2009),Türk Kamu Mali Yönetiminde İç Denetim ve İç Denetim Algısı, Yayımlanmamış Yüksek LisansTezi, Süleyman Demirel Üniversitesi SBE, Isparta.

Karaaslan, Erkan(2006),"5018 Sayılı Kamu Mali Yönetimi ve Kontrol Kanununa Göre Denetim”, Mali Hukuk Dergisi, Sayı 121, ss. $19-25$

Kaval, Hasan(2005),Muhasebe Denetimi, Gazi Kitabevi, Ankara.

Kayım, Ali(2006), İç Denetim ve İç Kontrol: Kavramsal Çerçeve, Vergi Raporu.

Korkmaz, Umut(2007),“Kamuda İç Denetim”, Bütçe Dünyası Dergisi, Cilt 2, Ankara, ss.4-15

Köksal, Erhan(1998),"Türkiye'de Merkezi Hükümetin Taşra Örgütünün Denetimi”, Amme İdaresi Dergisi, Cilt 20, Say1 3, Ankara, ss. 51-61

Köse, H.Ömer,(2000),Dünyada ve Türkiye'de Yüksek Denetim, Yayımlanmamış Doktora Tezi, İstanbul Üniversitesi SBE.

Mallı, İsmail(2013),Kamu Mali Yönetiminde İç Denetimin Önemi ve Farklı Ülkelerde Uygulanan İç Denetim Modellerinin Karşılaştırılması, Yayımlanmamış Yüksek Lisans Tezi, Gazi Üniversitesi EBE, Ankara, 2013

Önder, M. Fahrettin(2008),Türk Hukukunda İç Denetim ve Uluslararası Standartlara Uyum, Asil Yayınları, 276 s.,Isparta

Özen, Baran(2000), İç Denetim Standartları ve Mesleğin Yeni Açılımları, Sayıştay Yayınları, Ağustos, Ankara.

Saka, Tamer(2001), "İç Denetim Mesleği, Bankacılık ve Risk Yönetimi”, İç Denetim Dergisi, Türkiye İç Denetim Enstitüsü, Sayı 1, İstanbul, ss. 48-57

Toroslu, M. Vefa(2014), Türk Ticaret Kanunu Kapsamında İç Kontrol ve İç Denetim,Vedat Kitapçılık, İstanbul.

Yörüker,Sacit(1999),Denetim Terimleri, Sayıştay Yayınları, Ankara.

Maliye Hesap Uzmanları Derneği(1996), Denetim, Maliye Hesap Uzmanları Derneği Yayınları, İstanbul.

https://www.tide.org.tr/page.aspx?nm=IcDenetiminTanimi,

Erişim Tarihi (13.11.2016)

İç Denetçilerin Çalışma Usul Ve Esasları Hakkında Yönetmelik; Madde 8.

http://eprints.sdu.edu.tr/, Erişim Tarihi (18.12.2016)

http://www.mevzuat.gov.tr/MevzuatMetin/1.5.6085.pdf, Erişim Tarihi (13.10.2016). 